\section{The Yellowstone Park as a bison preserve.}

Permit me to thank you for your timely remarks in No. 103 upon the threatened extinction of the American bison. The question seems to be, as you state it, whether the bison (and with equal propriety, say I, a large number of other decadent types) can be successfully domiciled within the boundaries of the Yellowstone Park. Having given this subject careful attention, I am prepared to say that the practicability of the scheme admits of no reasonable doubt. The park itself is to-day one of the few regular retreats of the existing herds of buffaloes, and nothing but the protection intended by the laws is really needed for their preservation. Of late years much has been done by the superintendent and his efficient corps of aids, vigorously seconded by the territorial authorities of Wyoming. But the laws are not yet sufficiently punitory, and there is no provision for insuring the retention of the animals within the limits of the reservation. The superintendent, in a late report, refers to the presence of a few straggling bands at various points in the park, but apparently he considered them more as 'stragglers' than as legitimate denizens.

If the end in view, as suggested above, be the fostering of all animals which the national park may readily sustain, much more vigorous effort is demanded. The importation and semi-domestication of such exogenous forms as are in imminent danger of extinction should be encouraged; and why may we not look with great expectations upon such local scientific societies as are already organized in Denver and San Francisco? I have never seen a specimen of the Aplocerus montanus, nor have I met any one who has known it in its native haunts; but it is not wholly extinct. This species of antelope, incorrectly called the Rocky-mountain goat, should be preserved in the park, at all hazards. The big-horn (Ovis montana) is still living in Colorado and elsewhere; but it cannot long withstand the ravages of the hunter and the inroads of the mining industry. There is a very short lease of life for the grizzly bear under present conditions, and the beaver is rapidly disappearing.

Fortunately for our object, most of these animals have wandered into the park, and but little care will be required to retain them within its borders. Still there is needed some more capable and responsible supervision than has yet been secured by legislation; and experience has shown the influence which men of science have been able to exercise in similar cases. A committee of the American association for the advancement of science, appointed at the Nashville meeting, was able to obtain an appropriation from congress of ten thousand dollars, to be applied to the increase of accessibility to the geysers and thermal springs; and quite recently more has been done in that direction, and in the way of stopping lawlessness and depredations. Now is the time, and scientific men are the legitimate instruments, for completing the work by united action in support of this vast zoölogical garden, and of the collection of representatives of the many dying forms of our American fauna.

Cleveland, O., Jan. 27.

\section{The muskrat carnivorous.}

Some twenty years ago, and from that time on for ten years, I was in the habit, with some friends of similar tastes, of closely searching the river-banks of this vicinity, and the waters, too, when practicable, for the aquatic mollusks which then abounded. 'The muskrats, now nearly extinct among us, were then numerous; and we soon learned that they were excellent collectors of shells, bringing out great numbers of the deep-water mussels of several species not usually very easily found by us, and leaving the shells in perfect condition.

In the rocky banks were many caves where shells were thus gathered; and one, especially on the south bank of Rock Island, a large space, well sheltered, and above high water, contained many bushels, the accumulations, apparently, of a long period, but very fresh in appearance, and well preserved. Among. the species most numerous were Unio cornutus, U. metaneorus, U. securis, and U. pustulosus. Many other species were found in less numbers, - U. rectus very rarely (though numerous in the river), and $U$. monodontus never. These heaps we examined with the utmost care, and obtained hundreds of fine specimens. During those years the muskrats still inhabited these places, and, except in winter, constantly brought out quantities of fresh shells, which we conscientiously appropriated. It was also very common to find heaps of fresh shells on or beside a stump, $\log$, or rock, a few feet, or sometimes rods, from the water. We not infrequently found shells which had been gathered since the preceding day, as shown by shreds of the soft parts adhering to the shell being undried.

An open question with us, often asked but never answered, was, 'How do the rats open the mussels?' The first attempt at an explanation, which I remember to have seen, was in the remarks of Mr. W. S. Lee at a meeting of the Trenton natural-history society (Science, vol. iv. no. 94, p. v.).

Of course, we cannot gainsay what Mr. Lee has seen, that the animal ' apparently' held the mollusk's foot with his claws, preventing the closure of the shell. It would perhaps require a pretty strong grip to counteract the force of the powerful adductor muscles of the mollusk, with the pressure of the rat's paws at the same time tending to press the shell together. Again: one cannot help wondering how " the muskrat swam ashore, holding the mussel between the fore-paws," while the weight of the mussel would tend to pull the animal's head down, and, without the use of the fore-paws, how he could swim. We also wonder how, without relaxing his grip, he carried his burden, as was usually the case, to some distance from the water.

In Science, vol. v. p. 65, Mr. W. M. Beauchamp gives some curious explanations. He does not state where he saw "the statement that the carnivorous habits of the muskrat have but just been discovered by scientific men." Of course, everybody who knows the muskrat at all has always known that it is not worth while to bring proof of a fact so universally known.

"The four principal ways in which the muskrats get at the animal in the mussel-shell " may deserve a moment's attention. 10. In our experience, the Anodons among the muskrat-heaps were very rare: they evidently preferred Unios; and in no instance were the Anodons in the shell-heaps found in a condition indicating that one valve had been torn off to open it. It was not uncommon to find, just along the water's edge, the tracks of the raccoon; and along these tracks were often to be found the Anodons, with one shell torn off or crushed. The coon seemed to prefer the Anodon, probably having no means of opening the Unio. $2^{\circ}$. The Unios were never observed with 'the thinner end of the shell,' or either end or edge, broken away. $3^{\circ}$. While he 'has heard" that the rats sometimes gnaw away the hinge-liga- 